\title{
The Effect of Combining the Competency Based Approach and the Multiple Intelligences Theory on the Development of EFL Students' Speaking Skill
}

Received: 06/04/2019; Accepted: 30/09/2019

\section{Abstract}

This paper investigates the extent to which change of teaching style affects students' achievements, more specifically their development of the speaking skill within a specific academic subject-matter course. The researcher seeks to investigate whether learners' performance on a specific topical knowledge speaking test will be enhanced if we implement an instructional design that incorporates the principles of the Competency-Based Approach and the Multiple Intelligences Theory. In order to achieve the research objective, a quasi-experiment was implemented at the level of the English department- Larbi Ben M'hidi University. The study was conducted on three intact first-year groups and it went over three phases: pretesting, treatment, and post-testing. The research findings revealed that combining the Competency-Based Approach and the Multiple Intelligences Theory yields better results in students' development of the speaking skill.

Keywords: Competency based approach; English as a foreign language learning ; multiple intelligences theory ; speaking skill.

\section{Djallel BOULMAIZ*}

Faculty of Letters and Languages

Department of Foreign Languages

University of Mentouri Constantine 1, Algeria

\section{Résumé}

Cet article examine dans quelle mesure le changement de style d'enseignement influe sur les résultats des élèves, et plus particulièrement sur le développement de leur aptitude à parler dans le cadre d'un cours spécifique. Le chercheur essaie de déterminer si les performances des apprenants lors d'un test de connaissance théorique spécifique seront améliorées si nous mettons en œuvre une conception pédagogique intégrant les principes de l'approche par compétences et de la théorie des intelligences multiples. Afin d'atteindre l'objectif de la recherche, une quasi-expérience a été mise en place au niveau du département d'anglais, Université Larbi Ben M'hidi. L'étude a été menée sur trois groupes intacts de première année et s'est déroulée en trois phases: pré-test, traitement et posttest. Les résultats de la recherche ont révélé que la combinaison de l'approche par compétences et de la théorie des intelligences multiples donne de meilleurs résultats pour le développement des compétences à l'oral de l'élève.

Mots clés: Approche par compétences; théorie des intelligences multiples; Apprentissage de l'anglais comme langue étrangère; aptitude à parler.

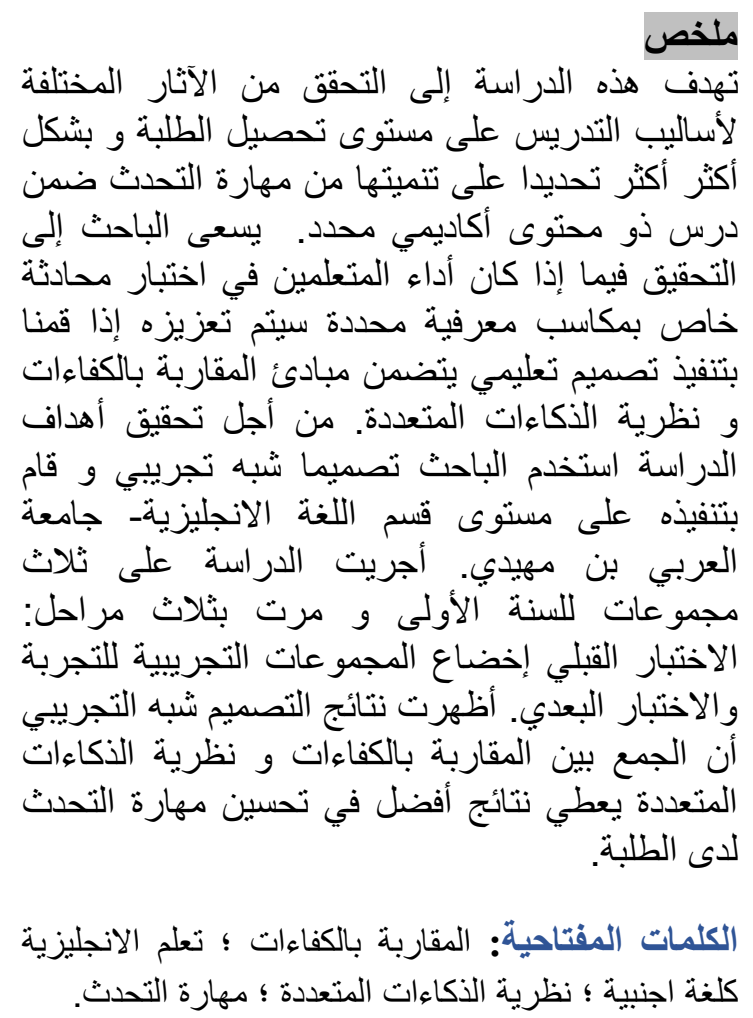




\section{I- Introduction}

The major aim of higher education is to prepare a highly-skilled and qualified workforce. There is, in fact, no one single route to develop successful individuals, but it is believed that the implementation of CBE along with the integration of MIT into our current teaching systems can be one of the best ways to make our community deliver rounded citizens that can lead productive, prosperous lives.

Students need to be prepared for a world that is not just looking for individuals who possess disciplinary knowledge, but rather for ones who own the competence of effectively utilizing such knowledge in practical, real-life situations. The target of the teaching process should go beyond transmitting abstract information to include qualifying our students to be better information processors, critical thinkers, and problem solvers.

The key to improving our learners' achievements may be in the hands of the students themselves. The solution may lie in adopting a teaching approach that caters more for learners' different profiles, an approach that makes students' needs its starting point, and one that encourages autonomy by giving students more control over the learning process. This study attempts, therefore, to investigate whether students' achievements will be boosted if we implement a learner-centered instructional design. This instructional design will draw on the principles of the Competency Based Approach (CBA) and the Multiple Intelligences Theory (MIT). It should be noted that the language skill our study will primarily target is the speaking skill. Our choice is justified by the fact that speaking is a very important skill that is rarely addressed and assessed within conventional systems.

\section{II- Competency Based Education}

Unlike input-based instructional approaches, which hinge on the assumption that effective learning will take place through the improvement of the syllabi and materials students will be exposed to, outcome-based approaches, such as CBA, contend that educators' focus should rather be directed towards what learners will be able to do by the end of the instruction. CBA is an approach where stakeholders responsible for the development of society and employment are involved by educational institutions in deciding about curricula, syllabi, and their objectives. It is more about making learners receive the type of instruction that would make them acquire the generic and specific competences required in the workplace. Sanchez and Ruiz (2008) define CBA as follows:

[It] consists in developing the necessary generic or transversal (instrumental, interpersonal and systemic) competences and the specific competences pertaining to each profession. The aim is to endow students with scientific and technical knowledge, and enable them to apply such knowledge in diverse complex contexts. To this end, knowledge is integrated along with attitudes and values in ways that are appropriate for each student's personal and professional life (p.33).

According to Garrett and Lurie (2016), Competency-Based Education (CBE) is:

An instructional system in which the time it takes to demonstrate competencies varies and the expectations about learning are held constant. Students acquire and demonstrate their knowledge and skills by engaging in learning exercises, activities, and experiences that align with clearly defined programmatic outcomes. Students receive proactive guidance and support from faculty and staff. Learners earn credentials by demonstrating mastery through multiple forms of assessment, often at a personalized pace (p. 2).

A more comprehensive definition was provided by Spady (1994) who states that CBE is:

a data-based, adaptive, performance-oriented set of integrated processes that facilitate, measure, record and certify within the context of flexible time parameters the demonstration of known, explicitly stated, and agreed upon learning outcomes that reflect successful functioning in life role (p. 22). 
This operational definition articulates the main characteristics of CBE and identifies the six critical elements which combine to generate a full-blown CBE program. These are:

$>$ Outcomes: Evidently, the most important aspect of this definition of CBE is the concept of competency. Unlike traditional programs, in which learners' success and failure was determined in closed classrooms through paper-pencil tests, competency based programs associate students' success with the attainment of the targeted competences. What is specific about CBE is that prospective life roles and their attendant activities are the prime movers in framing outcome goals and desired competences.

$>$ Time: CBE advocated a shift from a time-based to an outcome-based school organization. This means that opportunities for evaluation and instruction should not be necessarily determined within fixed time parameters. CBE makes it clear that learner's attainment of outcome goals should be teachers' prime concern and flexibility with the required time is highly advisable.

> Instruction: Teaching objectives within CBE are directly connected with the liferoles required of the learner after training. Instructional programs are designed in a way which guarantees that students be equipped with the necessary skills and competences needed at workplace. Instruction revolves around exposing learners to the range of experiences and activities that might promote success in a given area.

$>$ Measurement: Within CBE, assigning grades and making placement decisions is based on measurement criteria that are explicit, agreed upon, criterion-referenced, and known in advance by students. Clearly, CBE reduces the discretion of individual teachers in determining both the criteria to be used in evaluation and the uses to which the latter can be put.

$>$ Certification: In a competency based program, certification is earned only through competency demonstration. Learners are not simply certified according to such criteria as attendance and compiling some course credits.

$>$ Program adaptability: A salient characteristic of CBE programs is that they are highly dynamic. Learners' performances are a reflection not only of their ability and endeavor but of the adequacy and appropriateness of the instruction provided, the evaluation tools used, or the goals themselves. Educators should be continuously adapting their instructional programs to suit students' needs and they can take learners' performances as indicators (Spady 1994).

Competency-Based Language Teaching (CBLT) is an application of the principles of Competency-Based Education to language teaching. According to Nunan (2013) "teaching ESL to competencies requires the instructional focus to be on functional competencies and life-coping skills. It is not what the students know about language but what they do with the language" (p. 25). Auerbach (1986) identifies eight features involved in the implementation of CBLT programs in language teaching:

1. A focus on successful functioning in society. The goal is to enable students to become autonomous individuals capable of coping with the demands of the world.

2. A focus on life skills. Rather than teaching language in isolation, CBLT teaches language as a function of communication about concrete tasks. Students are taught just those language forms/ skills required by the situations in which they will function. These forms are normally determined by needs analysis.

3. Task- or performance-oriented instruction. What counts is what students can do as a result of instruction. The emphasis is on overt behaviors rather than on knowledge or the ability to talk about language and skills.

4. Modularized instruction. Language learning is broken down into meaningful chunks. Objectives are broken into narrowly focused sub-objectives so that both teachers and students can get a clear sense of progress.

5. Outcomes are made explicit. Outcomes are public knowledge, known and agreed upon by both learner and teacher. They are specified in terms of behavioral objectives so that students know what behaviors are expected of them.

6. Continuous and ongoing assessment. Students are pre-tested to determine what skills they lack and post-tested after instruction on that skill. If they do not achieve the desired level of mastery, they continue to work on the objective and are retested. 
7. Demonstrated mastery of performance objectives. Rather than the traditional paperand-pencil tests, assessment is based on the ability to demonstrate pre-specified behaviors.

8. Individualized, student-centered instruction. In content, level, and pace, objectives are defined in terms of individual needs; prior learning and achievement are taken into account in developing curricula. Instruction is not time-based; students progress at their own rates and concentrate on just those areas in which they lack competence (pp. 414-415).

The philosophical foundations that form the basis of CBLT originate from a behaviorist learning theory and an experimentalist view of education. Instead of basing instructional programs on the acquisition of knowledge, competency based curricula take as a starting point the analysis of what people need to do. However, Burns and Klingstedt (1972) pointed out that CBE can, and should, be viewed and utilized in different ways by educators adhering to thought patterns other than behaviorism and experimentalism. Dewey (1938, as cited in Burns \& Klingstedt, 1972), who is considered by many as the father of experimentalism, admitted that:

Any theory and set of practices is dogmatic which is not based upon critical examination of its own underlying principles. . . furthermore, anyone who is looking ahead to a new movement in education . . . should think in terms of education itself rather than in terms of some 'ism' about education, even such an 'ism' as 'progressivism' [experimentalism] (p. 13).

The competency based movement was able to adapt with the major changes fields like education and psychology have witnessed. CBLT has espoused ideas coming from the cognitive, constructivist, and humanistic camps. The concept of competence has been enlarged to include besides the discrete, observable behaviors the underlying attributes (such as knowledge, required cognitive capacities, and attitudes) and successful social, contextual coping strategies.

\section{III- Gardner's Theory of Multiple Intelligences}

In 1967, Gardner received, along with a group of researchers, the assignment of writing a book about "what had been established about human cognition through discoveries in the biological and behavioral sciences. Thus was born the research program that led to the theory of multiple intelligences" (Gardner, 2003, p. 3).

MIT came as a reaction to the traditional psychometric view. It regarded intelligence as more than just a unitary, quantitatively determined ability. Gardner, instead, saw the mind "as a series of relatively separate faculties, with only loose and non-predictable relations with one another" (Gardner, 1993, p. 32). Intelligence was, therefore, defined by Gardner as "a biopsychological potential to process information that can be activated in a cultural setting to solve problems or create products that are of value in a culture", (pp. 33-34). He "saw intelligent behavior as related to specific kinds of functioning in the real world" (Mason \& Wilox, 2009, p. 498).

Accordingly, Gardner introduced a list of seven intelligences: verbal/linguistic, logical/mathematical, spatial/visual, bodily/kinesthetic, musical, interpersonal, and intrapersonal. In 1999, however, he reconsidered his taxonomy and an eighth intelligence was added to the list, namely the naturalist intelligence. Below follows a brief description of the eight intelligences:

A/ Verbal/Linguistic Intelligence (VL): VL intelligence, according to Gardner (1999), entails acuteness in dealing with language forms, facility for languages, and adeptness at manipulating linguistic structures and using them effectively to achieve the desired objectives.

B/ Logical/Mathematical Intelligence (LM): Effectiveness in using logical reasoning, carrying out mathematical operations, and adopting scientific approaches to solve problems are all manifestations of LM intelligence (McKay, 2008; Kincheloe \& Feltman 2007).

C/ Musical Intelligence $(\boldsymbol{M})$ : $\mathrm{M}$ intelligence is characterized by sensitivity to rhythmic patterns and artistry in the creation and deciphering of musical pitches and tones (Gardner, 1999). 
D/ Bodily-kinesthetic intelligence (BK): BK intelligence involves the capacity to use the body to solve problems and carry out physical endeavors.

E/ Spatial/Visual Intelligence (SV): SV intelligence is characterized by powerful mental imagery. It entails success in solving problems through effective generation of mental representations of the physical space (Gardner, 1999).

F/ Interpersonal Intelligence (IR): IR intelligence is characterized by the capacity to comprehend, evaluate, and cope with other peoples' emotions, desires, thoughts and psyches. It involves a person's ability to successfully interpret others' facial expressions, gestures, and verbal cues (Gardner, 1999)

G/ Intrapersonal Intelligence (IA): IA intelligence involves, according to Gardner, "the capacity to understand oneself, to have an effective working model of oneselfincluding one's own desires, fears, and capacities - and to use such information effectively in regulating one's own life" (Gardner, 1999, p. 43).

H/ Naturalistic Intelligence $(N)$ : Naturalistically intelligent people demonstrate expertise in coping with environmental issues and show great interest in the fauna and flora and (McKay, 2008; and Kincheloe \& Feltman, 2007).

\section{IV- MI Theory and Education}

Gardner's theory of multiple intelligences came originally as an attempt to broaden the concept of human cognition. "Gardner did not develop MI theory with an intended educational agenda or audience" (Seider \& Gardner, 2009, p. 637). The impact it had on the educational world, however, was massive. Right after its inception, Gardner (2003) started receiving a steady stream of communications from instructors consulting him about effective ways for integrating MIT into their current teaching practices. MIT was embraced with great enthusiasm by the schooling society and it has indeed "provided a useful framework for improving school-based practice in the areas of curricula, instruction, and assessment" (Chen, 2002, p. 1199).

VL and LM intelligence dominated traditional schooling on the grounds that these too abilities can be measured and compared with less difficulty. Armstrong (2003) pointed up, as well, the role played by our culture in assigning, unjustifiably, more importance to the $\mathrm{VL}$ intelligence at the expense of other intelligences. Multiple intelligences based instruction, however, invigorated interest in the six non-traditional intelligences (SV, BK, M, IR, IA, and N) that have been often overlooked in conventional systems.

Chen (2002) justifies the importance of providing variety in educational settings by stating that "each child's biopsychological potential is different, providing a broad range of subject areas at a young age also increases the likelihood of discovering interests and abilities that can be nurtured and appreciated" (p. 1200). Catering for students' multiple intelligences would breed not only more engaged learners but also more inclined and competent citizens. MIT aids in achieving goals broader than those strictly attached to the academic context (Gardner, 1983). Furthermore, the fact that we use different combinations of intelligences when we perform daily tasks, as pointed out by Tele (2000), supports the call for MIT implementation.

Evidence of the Value of MIT was demonstrated through many studies and research projects. In the late 1990s, Mindy Kornhaber conducted a study, as part of Harvard's Project Zero, in which she reported the results documented by forty one US elementary schools after applying MI theory to school-based practice for at least three years. Most of the schools "reported improvement in standardized-test scores, student discipline, parent participation, or performance of students with learning differences" (Chen, 2002, p. 1200). Another research project, Project Spectrum, which was a tenyear study conducted between 1984 and 1993, investigated the effect of multiple intelligences based instruction on at-risk first grade students. The study reported that students who were at risk for school failure were not necessarily low performers in all domains. More importantly, "identifying and nurturing these at-risk children's strengths led to statistically significant increases in these children's self-direction, selfconfidence, positive classroom behavior, positive affect, self-monitoring, and active engagement" (Seider \& Gardner, 2009, p. 638). 


\section{V- Methodology}

\section{V.1. Research Method}

This study sets as a goal investigating the differential effects three different teaching styles may have on learners' speaking performance on a specific topical knowledge test. A quasi-experimental design was opted for in order to examine how change in teaching style affects the development of learners' ability to express knowledge of a specific academic content orally. The research is merely quasiexperimental because the participants were not randomly chosen by the researcher; they were rather assigned to different groups by the English department administration at Larbi Ben M'hidi University.

\section{V.2. Participants}

Participants in this study are first year LMD students from the department of English at Larbi Ben M'hidi university in the academic year 2015/2016. Three groups were selected and assigned randomly to control and experimental groups "A" and "B". Only sixteen students from each group were part of the study because the researcher had to eliminate learners who did not attend regularly, learners who did not carry out the tasks required of them, and those who did not take the pre and/or post test.

\section{V.3. Instrumentation}

The present study investigates whether difference in teaching style would affect learners' speaking performance in a linguistics class. Thus, the research was an attempt to establish a causal relationship between two variables:

-The dependent variable, which is learners' development of the ability to express knowledge of a specific academic content orally.

-The independent variable, which is, as stated before, teaching style. The independent variable in this study has three levels:

1) Teaching using the traditional method where students are passive receivers of information.

2) Teaching by implementing the principles of CBA.

3) Combining the principles of CBA and MIT.

Experimentation was, therefore, used as the main method for gathering data and testing the research hypotheses which were formulated as follows:

H1: Experimental group $A$ will outperform the control group in the specific topical knowledge speaking test.

$\mathrm{H} 2$ : Experimental group $B$ will outperform both the control group and experimental group $A$ in the specific topical knowledge speaking test.

And the null hypothesis which was formulated as:

H0: 'Change in the teaching style will have no effect on students' development of speaking performance on a specific topical knowledge test'. In statistical terms, there will be no statistically significant difference between learners' performance on the specific topical knowledge speaking test across the three groups.

The schema of the study was organized in the following way:

The design: quasi-experimental

Control group: 16 students.

Experimental group A: 16 students.

Experimental group B: 16 students.

Duration: The study was carried out over the whole academic year 2015/2016. Students of the three groups took the pre-test in the second week of September 2015 and the post-test was administered in the first week of May 2016. The total number of treatment sessions was twenty five sessions; one hour and a half per week.

\section{V.4. The Procedure}

The study began by selecting, randomly, three groups: a control group and two experimental ones. Then, the research went through the following three important phases: 


\section{V.4.1. The Pre-test}

The speaking test was designed and developed by the researcher. This pre-test was administered to three intact groups during the second week of September, 2015 at the level of the English department at Larbi Ben M'hidi university- Oum el Bouaghi. It was in the form of an interview and it was comprised of two main parts. First, a warm up phase where students were asked some biographical questions just to prepare them and make them feel more relaxed and comfortable. After that, participants were asked more specific questions (six questions precisely) about language and linguistics (Appendix A).

The main purpose of the pre-test was to assess learners' background knowledge in that specific field, linguistics, before the implementation of three different instructional methods in order to investigate the effect of each teaching style on the development of participants' ability to express knowledge of a specific academic content orally.

Students' performance on the pre-test was scored on a scale from one to sixteen. The researcher relied on three main criteria to evaluate learners' performance: -Accuracy (5 points) -Fluency (5 points) -Specific topical knowledge (6 points)

Accuracy and fluency were evaluated according to two five-scale checklists respectively (Appendix C) and specific topical knowledge was scored out of six because learners were asked six questions (about language and linguistics); one point for each correct and complete answer.

It is worth mentioning that the researcher did not score the pre-test on the spot; the participants' speaking performance was recorded and evaluated later according to the aforementioned criteria.

\section{V.4.2. The Treatment}

After the administration of the pre-test, experimental group $A$ and experimental group $B$ underwent a treatment period which lasted the whole academic year 2015/2016, precisely, twenty five weeks with one session of ninety minutes per week. It is worth reiterating that the experiment was conducted in a linguistics class.

During that treatment period, two different teaching styles were implemented; each group received the same content using a different instructional method.

First, the instructional method that was used with experimental group $A$ was competency based (Appendix D). The teacher/researcher within this approach tried to move away from the traditional, teacher-centered methods that grant the learners no opportunity to take the initiative and exhibit their creativity. This approach is more learner-centered and therefore required students to be more active. Learners were all the time made aware of the objectives of each course beforehand and were therefore more responsible for their own learning since they had to collaborate together and with their teacher to reach those set objectives.

Second, with experimental group $B$, an instructional design where multiple intelligence-based techniques, coupled with CBA, was implemented (Appendix E). Combining the learner-centered approach (CBA) and theory (MIT) made learners' roles in the classroom exceed being plain passive receivers of knowledge. Furthermore, the implementation of MI-based instruction guaranteed more variation; it allowed students to perceive information and deploy their skills in a multitude of ways across various domains.

When implementing MIT, the researcher took account of three main factors: a) Content of the course, b) age of the students and c) means available to the researcher.

The researcher made sure that the way he engaged experimental group $B$ multiple intelligences, as illustrated in lesson plans $B$ (Appendix E)., was appropriate to the course content and to the learners' age. For example, it was difficult to incorporate a large number of activities from the bodily-kinesthetic or musical domains. If it were a general English course, more diversification would have been possible, if not needed, but since it was about presenting specific content lectures, we had to choose activities and techniques that match the nature of the content covered in this module. 
The control group, it should be pointed out, received no treatment. Over the same period of time, students of this group were taught using the traditional method; learners were merely passive recipients of information(Appendix F).

\section{V.4.3. The Post-test}

The post-test took the same form as the pre-test, an interview. It was therefore comprised of two main parts: First, a warm up phase where students were given the chance to be readied and relaxed. After that, they were asked six questions that specifically relate to language and linguistics; questions similar to the pre-test questions. In order to eliminate the possibility that it is only the learners' memorization that is being tested, questions from the pretest were paraphrased by the researcher to ensure that participants taking the post-test will be rather tested on their understanding of the materials. The post-test was administered in the first week of May, 2016.

Similar to the pretest grading procedure, the posttest was not scored by the time learners answered the questions. Students' responses were recorded and evaluated later according to the same criteria used in scoring the pre-test (accuracy $(5 / 5)$, fluency $(5 / 5)$, and specific topical knowledge (6/6) ). (Appendix B)

It should be reiterated that the researcher selected only 16 students to eventually take the post-test. Some participants were eliminated due to the following reasons:

- Some students did not take the pretest and/or the posttest so it was not possible to make them part of the study; the progress they could have made during the treatment period could not be traced or documented.

- Some students (from experimental groups $A$ and $B$ ) did not attend regularly and others did not carry out the projects or the home-works they were assigned. Eliminating this category of subjects was an obvious decision as they cannot be considered as students receiving the treatment implemented in this study.

\section{VI- Results Analysis}

The Statistical Package for the Social Sciences (SPSS) version 21 was used to describe and analyze data for this study. To make the reading and interpretation of data easier and more organized, we went through the following steps:

- The researcher started by carrying out some necessary descriptive statistics;

$>$ First, an account of the participant's scores in the pre-test and post-test was reported.

$>$ Second, data obtained from the three groups (the control group and experimental groups $\mathrm{A}$ and $\mathrm{B}$ ) in the pre and post-tests were compared via the calculation of the mean, median, mode, standard deviation and frequency distribution of scores.

- After that, another set of statistical measures, known as inferential statistics, were used to examine the relationship between the variables of the study. So:

$>$ The researcher conducted a between groups one way Analysis of Variance (ANOVA) to test the null hypothesis.

$>$ After that, to test the alternative hypotheses, compare between the results of the three groups in the post-test, and determine which group means are significantly different from each other, we undertook a planned comparisons test.

\section{VI.1. Scores Frequency Distribution}

As mentioned earlier, participants' performance in both the pre-test and the posttest were graded out of sixteen (16) and their results were as follows:

\section{VI.1.1 Scores Frequency Distribution of the Three Groups in the Pre-test}

Tables 1, 2, and 3 illustrate that pre-test scores in the three groups ranged from " 5 " to "7.5". 
The Effect of Combining the Competency Based Approach and the Multiple Intelligences Theory on the Development of EFL Students' Speaking Skill

Table 1. The Control Group Scores Frequency Distribution in the Pre-test

\begin{tabular}{|c|c|c|c|c|c|}
\hline & & Frequency & Percent & $\begin{array}{c}\text { Valid } \\
\text { Percent }\end{array}$ & $\begin{array}{c}\text { Cumulative } \\
\text { Percent }\end{array}$ \\
\hline \multirow{6}{*}{ Valid } & 5.00 & 2 & 12.5 & 12.5 & 12.5 \\
\hline & 5.50 & 3 & 18.8 & 18.8 & 31.3 \\
\hline & 6.00 & 6 & 37.5 & 37.5 & 68.8 \\
\hline & 6.50 & 4 & 25.0 & 25.0 & 93.8 \\
\hline & 7.00 & 1 & 6.3 & 6.3 & 100.0 \\
\hline & Total & 16 & 100.0 & 100.0 & \\
\hline
\end{tabular}

Table 2. Experimental Group A Scores Frequency Distribution in the Pre-test

\begin{tabular}{|c|c|c|c|c|c|}
\hline & & Frequency & Percent & $\begin{array}{c}\text { Valid } \\
\text { Percent }\end{array}$ & $\begin{array}{c}\text { Cumulative } \\
\text { Percent }\end{array}$ \\
\hline \multirow{7}{*}{ Valid } & 5.00 & 3 & 18.8 & 18.8 & 18.8 \\
\hline & 5.50 & 3 & 18.8 & 18.8 & 37.5 \\
\hline & 6.00 & 7 & 43.8 & 43.8 & 81.3 \\
\hline & 6.50 & 1 & 6.3 & 6.3 & 87.5 \\
\hline & 7.00 & 1 & 6.3 & 6.3 & 93.8 \\
\hline & 7.50 & 1 & 6.3 & 6.3 & 100.0 \\
\hline & Total & 16 & 100.0 & 100.0 & \\
\hline
\end{tabular}

Table 3. Experimental Group B Scores Frequency Distribution in the Pre-test

\begin{tabular}{|c|c|c|c|c|c|}
\hline & & Frequency & Percent & $\begin{array}{c}\text { Valid } \\
\text { Percent }\end{array}$ & $\begin{array}{l}\text { Cumulative } \\
\text { Percent }\end{array}$ \\
\hline \multirow{6}{*}{ Valid } & 5.00 & 3 & 18.8 & 18.8 & 18.8 \\
\hline & 5.50 & 4 & 25.0 & 25.0 & 43.8 \\
\hline & 6.00 & 4 & 25.0 & 25.0 & 68.8 \\
\hline & 6.50 & 2 & 12.5 & 12.5 & 81.3 \\
\hline & 7.00 & 3 & 18.8 & 18.8 & 100.0 \\
\hline & Total & 16 & 100.0 & 100.0 & \\
\hline
\end{tabular}

According to my experience, teaching this module (linguistics) for at least three years before carrying out this research, first year students come equipped with limited linguistic skills and enter this course having restricted background knowledge about that subject matter. I was, therefore, expecting the same from the participants in this study. This was confirmed after the pre-test was administered. Just from the scores frequency distribution tables, we can notice that, at the beginning of the study, the learners' achievements were low. Most importantly, we notice as well that students' levels in each group and also across the three groups were close; the difference between the highest mark and the lowest one was only 2.5 .

From figure 1, we can see clearly that the control group and the two experimental groups' scores frequencies in the pre-test are approximately similar in most cases.

Figure 1. The Three Groups Scores Frequency Distribution in the Pre-test 


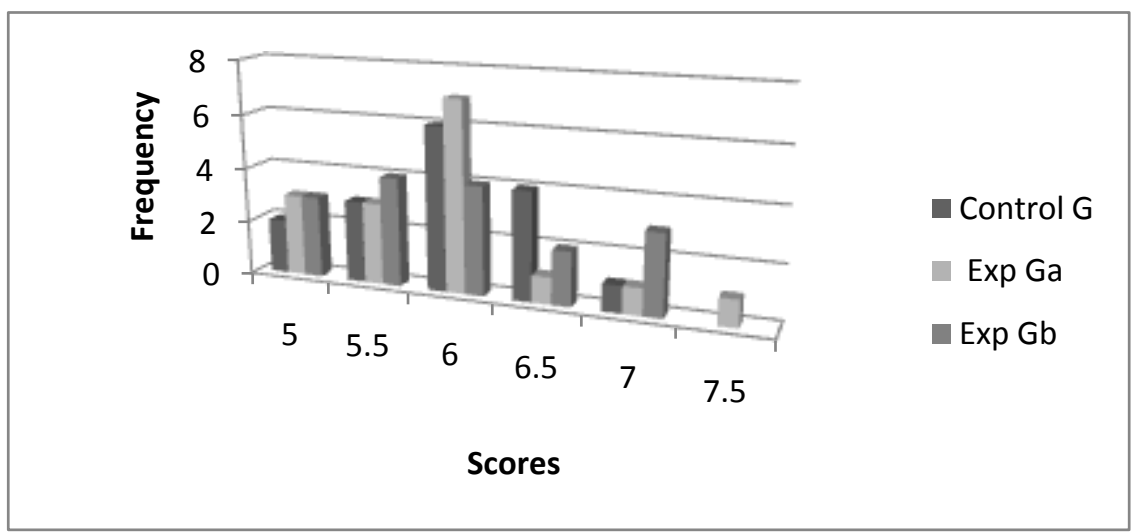

To get a clearer image and make a better reading of the data of the participants' scores in the pre-test, we had to measure central tendency and represent the center of our data set. For that purpose, three basic statistics were used: the mean, the median, and the mode. It should be noted that we have also used standard deviation as a measure of dispersion.

The mean is the most commonly used measure of central tendency. It is the sum of scores divided by the total number of scores. As displayed in table 4, the three groups mean scores were as follows:

$$
\text { X } \mathrm{X} \text { Cpre }=5.96 \quad \overline{\mathrm{X}} \text { Eapre }=5.90 \quad \overline{\mathrm{X}} \text { Ebpre }=5.93
$$

(Where $\overline{\mathrm{X}}_{\text {Cpre refers to the control group mean value, }} \overline{\mathrm{X}}_{\text {Eapre refers to experimental }}$ group A mean, and $\overline{\mathrm{X}}_{\text {Ebpre refers to experimental group mean score). }}$

We notice here that the mean values of the three groups are very close and the difference between them is not significant.

Table 4. Mean, Median, Mode, and Standard Deviation of the Three Groups in the Pre-test

\begin{tabular}{|l|r|r|r|}
\hline & $\begin{array}{c}\text { Control Gr } \\
\text { Pre-test }\end{array}$ & $\begin{array}{r}\text { Experimental } \\
\text { Gr A Pre-test }\end{array}$ & $\begin{array}{r}\text { Experimental } \\
\text { Gr B Pre-test }\end{array}$ \\
\hline N Valid $\quad 16$ & 16 & 16 \\
Mean & 0 & 0 & 0 \\
Median & 5.9688 & 5.9063 & 5.9375 \\
Mode & 6.0000 & 6.0000 & 6.0000 \\
Std. Deviation & 6.00 & 6.00 & 6.00 \\
& .56181 & .68845 & .70415 \\
\hline
\end{tabular}

In addition to that, Table.4 illustrates that the most repeated value (the mode) in the control group and the experimental groups as well was " 6 ". The median was also the same across the three groups, " 6 ".

The distribution of data is symmetric, meaning that both halves of the distribution curve around the midpoint are mirror images of each other, because the mean and the median (of the three groups) were at approximately the same point (also because the standard deviation in the three groups is small: 0.5/0.6/0.7 respectively).

The collected data demonstrate clearly that achievement scores of students from the control group, experimental group $A$, and experimental group $B$ in the pre-test were comparable to a great extent. We can safely declare that students, across the three groups, had approximately the same proficiency level before the treatment period.

\section{VI.1.2. Scores Frequency Distribution of the Three Groups in the Post-test}

As displayed in tables 5, 6, and 7, participants' post-test scores ranged from " 6 " to " 9 " in the control group, from " 7.5 " to " 13.5 " in experimental group A; and from "10" to "14" in experimental group B. 
The Effect of Combining the Competency Based Approach and the Multiple Intelligences Theory on the Development of EFL Students' Speaking Skill

Table 5. The Control Group Scores Frequency Distribution in the Post-test

\begin{tabular}{|c|c|c|c|c|c|}
\hline & & Frequency & Percent & $\begin{array}{l}\text { Valid } \\
\text { Percent }\end{array}$ & $\begin{array}{c}\text { Cumulative } \\
\text { Percent }\end{array}$ \\
\hline \multirow{7}{*}{ Valid } & 6.00 & 2 & 12.5 & 12.5 & 12.5 \\
\hline & 6.50 & 2 & 12.5 & 12.5 & 25.0 \\
\hline & 7.00 & 6 & 37.5 & 37.5 & 62.5 \\
\hline & 7.50 & 3 & 18.8 & 18.8 & 81.3 \\
\hline & 8.00 & 2 & 12.5 & 12.5 & 93.8 \\
\hline & 9.00 & 1 & 6.3 & 6.3 & 100.0 \\
\hline & Total & 16 & 100.0 & 100.0 & \\
\hline
\end{tabular}

Table 6. Experimental Group A Scores Frequency Distribution in the Post-test

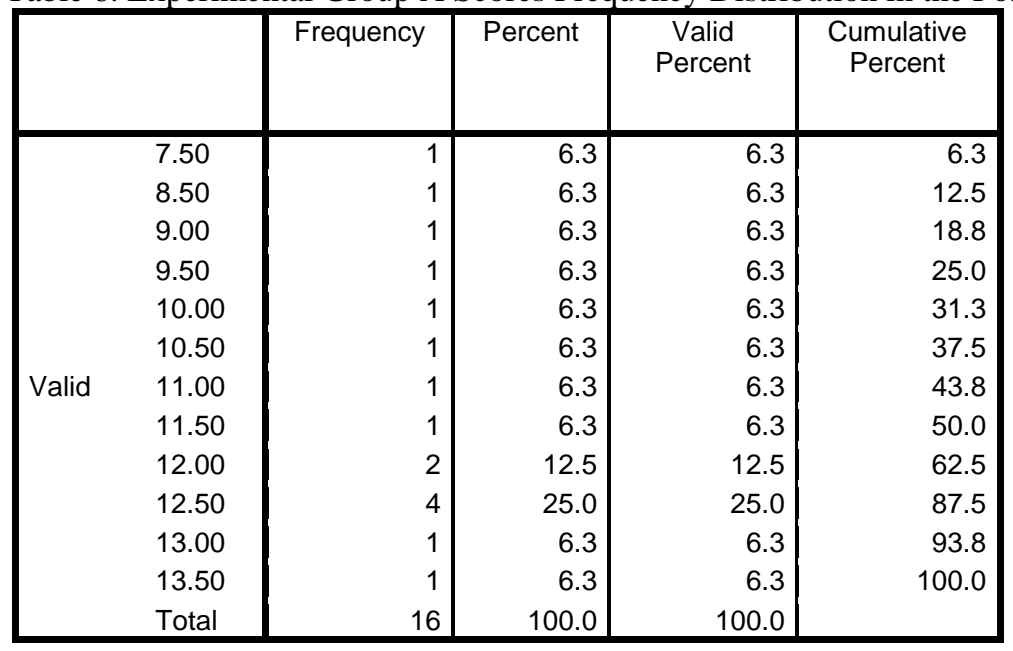

Table 7. Experimental Group B Scores Frequency Distribution in the Post-test

\begin{tabular}{|c|c|c|c|c|c|}
\hline & & Frequency & Percent & Valid Percent & $\begin{array}{l}\text { Cumulative } \\
\text { Percent }\end{array}$ \\
\hline Valid & $\begin{array}{l}10.00 \\
11.50 \\
12.00 \\
12.50 \\
13.00 \\
13.50 \\
14.00 \\
\text { Total }\end{array}$ & $\begin{array}{r}2 \\
1 \\
2 \\
2 \\
5 \\
3 \\
1 \\
16\end{array}$ & $\begin{array}{r}12.5 \\
6.3 \\
12.5 \\
12.5 \\
31.3 \\
18.8 \\
6.3 \\
100.0\end{array}$ & $\begin{array}{r}12.5 \\
6.3 \\
12.5 \\
12.5 \\
31.3 \\
18.8 \\
6.3 \\
100.0\end{array}$ & $\begin{array}{r}12.5 \\
18.8 \\
31.3 \\
43.8 \\
75.0 \\
93.8 \\
100.0\end{array}$ \\
\hline
\end{tabular}

Figure 2. The Three Groups Scores Frequency Distribution in the Post-test 


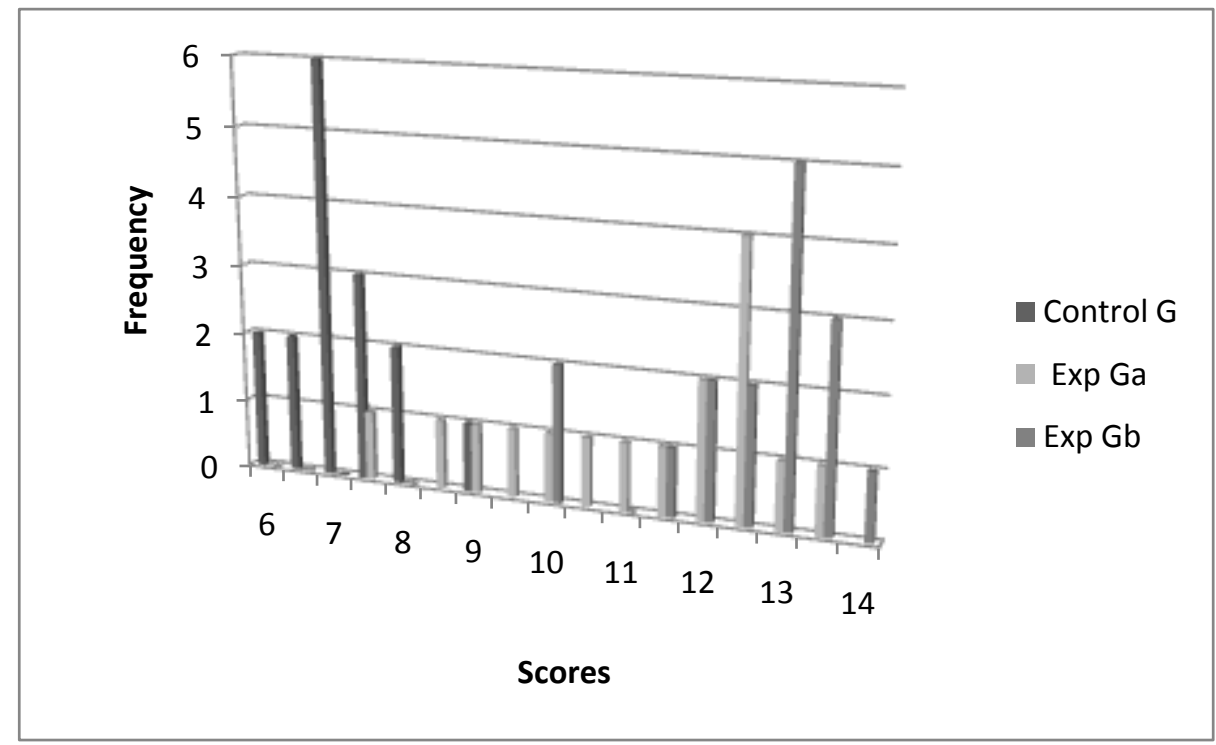

Table 8 shows that students from experimental group $A$ and experimental group $B$ have clearly outperformed the control group students. And participants from experimental group $B$, in turn, have outperformed experimental group $A$ students.

Table 8. Mean, Median, Mode, and Standard Deviation of the Three Groups in the Post-test

\begin{tabular}{|l|r|r|r|}
\hline & $\begin{array}{c}\text { Control } \\
\text { Group Post- } \\
\text { test }\end{array}$ & $\begin{array}{c}\text { Experimental } \\
\text { Group A } \\
\text { Post-test }\end{array}$ & $\begin{array}{c}\text { Experimental } \\
\text { Group B } \\
\text { Post-test }\end{array}$ \\
\hline $\mathrm{N} \quad$ Valid & 16 & 16 & 16 \\
Mean $\quad$ Missing & 0 & 0 & 0 \\
Median & 7.1563 & 11.1250 & 12.5000 \\
Mode & 7.0000 & 11.7500 & 13.0000 \\
Std. Deviation & 7.00 & 12.50 & 13.00 \\
\hline
\end{tabular}

There is a considerable difference between the mean scores of the three groups:

$$
\overline{\mathrm{X}}_{\text {Cpost }}=7.15 \quad \overline{\mathrm{X}}_{\text {Eapost }}=11.12 \quad \overline{\mathrm{X}}_{\text {Ebpost }}=12.5
$$

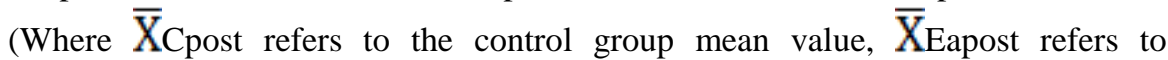
experimental group A mean, and $\overline{\mathrm{X}}$ Ebpost refers to experimental group mean score).

We can notice from table 8 and histogram 1 that data obtained from the control group were normally distributed; the values of the mean, median, and mode (7.15, 7 , and 7 respectively) were at approximately the same point with a small standard deviation (0.76). This means that students' scores in the control group did not vary too much.

Results recorded by experimental groups $A$ and $B$, as clearly demonstrated in table 8 and histograms 2 and 3, show that data were slightly skewed to the left. We had the mean scores of both experimental groups to the left of the median, $\overline{\mathrm{X}}_{\text {Eapost }}=11.12$ to 11.75 and $\overline{\mathrm{X}}_{\text {Ebpost }}=12.5$ to 13 with relatively high standard deviations; 1.77 and 1.17 respectively. Consequent upon the finding that data were slightly skewed, the mode was considered as the best indicator of central tendency. Experimental group B's mode (13) was higher than the modal value of data obtained from experimental group A (12.5).

Histogram 1. Control Group Scores Frequency Distribution in the Post-test 


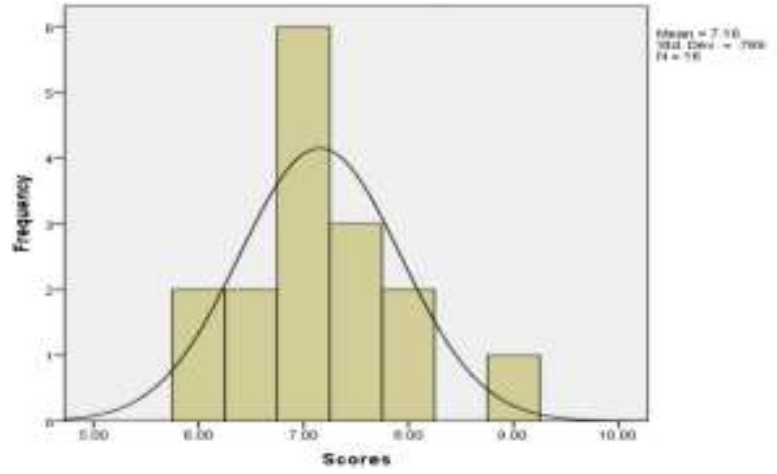

Histogram 2. Experimental Group A Scores Frequency Distribution in the Post-test

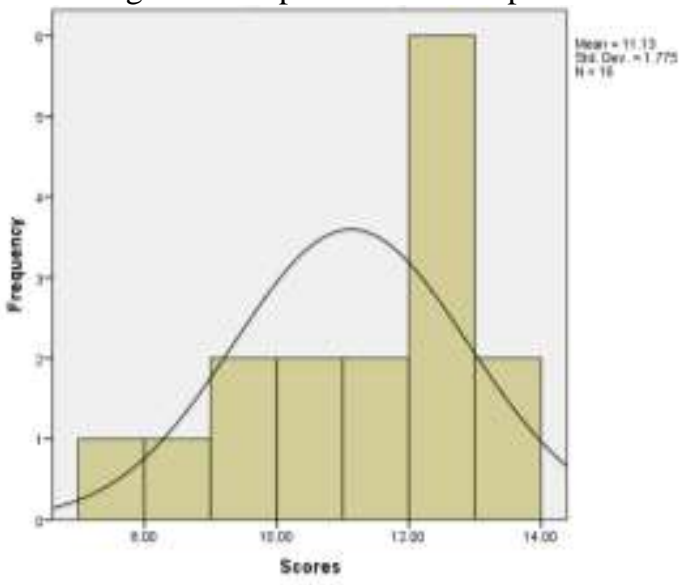

Histogram 3. Experimental Group B Scores Frequency Distribution in the Post-test

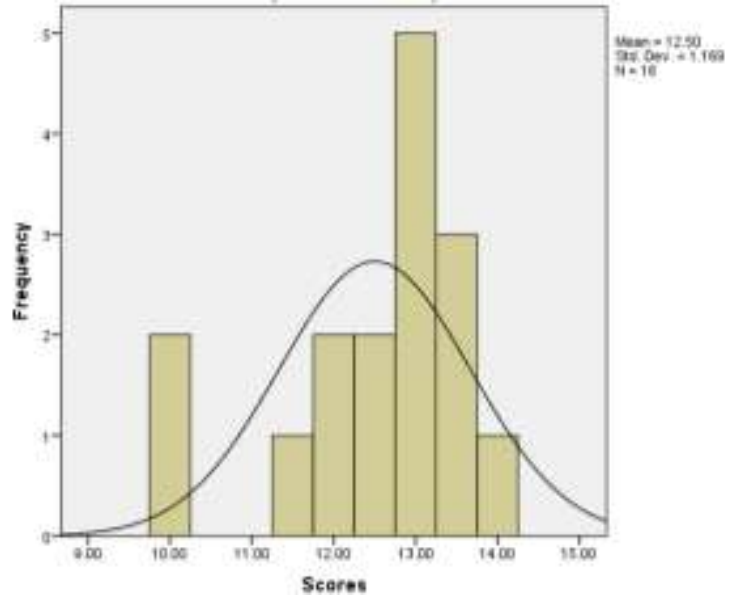

To sum up, the descriptive statistics carried out so far showed that the participants started from the same level because their scores in the pre-test were comparable to a great extent. Then, after going through the treatment period, students in the three groups made some improvement. It is clear though that while students' achievements have improved significantly in both experimental groups $A$ and $B$, participants from the control group did not make a similar progress.

\section{VI.2. Testing the Hypotheses}

A research report would usually seek to generalize the findings of the study from the selected sample to a wider population. Large amounts of data can be made user-friendly by applying descriptive statistics but they cannot be enough if the purpose is to make the claim that results obtained from the sample are valid to the whole target 
population as well. To attain such an aim, implementing inferential statistics is indispensible.

"Inferential statistics are those that can be used to make inferences to the population that the sample is assumed to come from" (Larson-Hall 2010, p.44). They are, therefore, typical for testing hypotheses about relationships between variables and deciding whether any change on the dependent variable of the study is due to the manipulation the independent variable.

A massive number of statistical measures are available to the researcher and choice of the right kind of statistical analysis depends on the nature of the gathered data and on the particular questions the researcher is trying to answer (Crawley, 2015). The inferential statistics we decided to employ then are the following:

- The between groups one way ANOVA: We decided to use this statistical measure to test the null hypothesis because it the most appropriate one when the aim is to examine the difference between more than two groups.

- The planned comparisons test: Which is a test used to make all possible comparisons between the three groups' achievements. For that reason, it is a necessary procedure for testing the alternative hypotheses of the study.

\section{VI.2.1. Testing the Null Hypothesis}

The main aim of this study is to investigate the relationship between two variables. First, students' performance on a specific topical knowledge speaking test; which is the dependent variable. Second, teaching style which is the independent variable.

The independent variable in this research is organized at three levels:

- Teaching using the traditional method.

- $\quad$ Teaching using CBA

- $\quad$ Teaching using CBA and MIT combined.

To conduct the research it was necessary to choose three groups to be the sample of this study. The first group was taught in a traditional way (the control group). With the second group the teacher/researcher implemented CBA and with the third group both CBA and MIT where applied.

The null hypothesis of the research was then formulated as follows:

H0: Change in teaching style (the traditional method, CBA, or CBA and MIT combined) will not have an effect on students' performance on specific topical knowledge speaking test.

Since we were planning on the examination of the difference between three groups mean scores, the most appropriate inferential statistical measure to employ was the Between Groups One Way ANOVA. Kerr, Hall, and Kozub (2002) stated that: "One-way ANOVAs are employed to address research questions that focus on the difference in the means of one dependent variable and one independent variable with two or more levels" (p. 79).

So, the null hypothesis predicted that there will be no statistically significant difference between the means of the control group, experimental group A and experimental group B in the post-test. To check the validity of this hypothesis we run a between groups one way ANOVA using SPSS software and the results were as follows: 
The Effect of Combining the Competency Based Approach and the Multiple Intelligences Theory on the Development of EFL Students' Speaking Skill

Table 9. Descriptives

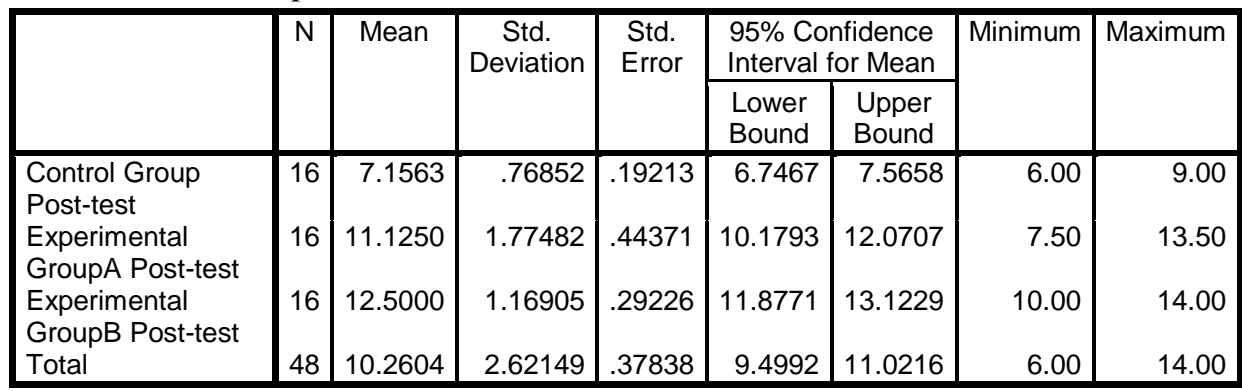

Table 10. Test of Homogeneity of Variance Results

\begin{tabular}{|r|r|r|r|}
\hline \multicolumn{1}{|c|}{ Levene Statistic } & df1 & df2 & \multicolumn{1}{|c|}{ Sig. } \\
\hline 6.525 & 2 & & 45 \\
\hline
\end{tabular}

Table 10 displays the results of the homogeneity of variance test. "In testing the homogeneity of variance assumption researchers hope that the probability will be greater than 0.05 as they want to accept the null hypothesis that the variances are not significantly different" (Kerr, Hall, and Kozub, 2002, p.91). The Levene test we conducted found that the assumption of homogeneity of variance was not met, $p=$ .003 .

We carried out then an ANOVA test and results are illustrated in table 11:

Table 11. ANOVA Test Results

\begin{tabular}{|l|r|r|r|r|r|}
\hline & \multicolumn{1}{|c|}{$\begin{array}{c}\text { Sum of } \\
\text { Squares }\end{array}$} & df & $\begin{array}{c}\text { Mean } \\
\text { Square }\end{array}$ & $\mathrm{F}$ & Sig. \\
\hline Between Groups & 246.385 & 2 & 123.193 & 72.363 & .000 \\
Within Groups & 76.609 & 45 & 1.702 & & \\
Total & 322.995 & 47 & & & \\
\hline
\end{tabular}

The ANOVA revealed a significant between-group effect of teaching style change (the independent variable) on the participants' performance on a specific topical knowledge speaking test (the dependent variable), $F(2,45)=72.36, P<.001$.

Since the $p$ value is less than .05 (which means that only $5 \%$ of the results is due to chance while $95 \%$ are likely to be sure) the null hypothesis is rejected.

\section{VI.2.2. Testing the Research Hypotheses}

The ANOVA test allows the researcher to only check whether or not all of the groups' means are equal; it does not help in the identification of which means are significantly different from each other. To test the set alternative hypotheses, we had to contrast the control group mean with the two experimental groups means, and also compare between the means of experimental group A and experimental group B. For that purpose, we employed a planned contrasts test which is used when you wish to test specific preplanned hypotheses concerning the differences between a subset of your groups (Tavakoli 2012).

The research hypotheses were formulated in the following way:

H1: Experimental group $A$ will outperform the control group in the specific topical knowledge speaking test.

$\mathrm{H} 2$ : Experimental group $B$ will outperform both the control group and experimental group $A$ in the specific topical knowledge speaking test.

Tables 12 and 13 display results of the planned comparisons test: 
Table 12. Contrasts Coefficients

\begin{tabular}{|c|c|c|c|}
\hline \multirow[t]{2}{*}{ Contrast } & \multicolumn{3}{|c|}{ Group } \\
\hline & $\begin{array}{c}\text { Control Group Post- } \\
\text { test }\end{array}$ & $\begin{array}{c}\text { Experimental GroupA } \\
\text { Post-test }\end{array}$ & $\begin{array}{c}\text { Experimental GroupB } \\
\text { Post-test }\end{array}$ \\
\hline $\begin{array}{l}1 \\
2\end{array}$ & $\begin{array}{l}1 \\
0\end{array}$ & $\begin{array}{r}-1 \\
1\end{array}$ & $\begin{array}{c}0 \\
-1\end{array}$ \\
\hline
\end{tabular}

Table 13. Planned Contrasts Test Results

\begin{tabular}{|c|c|c|c|c|c|c|c|}
\hline & Contrast & & $\begin{array}{l}\text { Value of } \\
\text { Contrast }\end{array}$ & $\begin{array}{l}\text { Std. } \\
\text { Error }\end{array}$ & $\mathrm{t}$ & df & $\begin{array}{l}\text { Sig. (2- } \\
\text { tailed) }\end{array}$ \\
\hline \multirow{4}{*}{ Scores } & \multirow{2}{*}{ Assume equal variances } & 1 & -3.9688 & .46131 & -8.603 & 45 & .000 \\
\hline & & 2 & -1.3750 & .46131 & -2.981 & 45 & .005 \\
\hline & \multirow{2}{*}{ Does not assume equal variances } & 1 & -3.9688 & .48352 & -8.208 & 20.434 & .000 \\
\hline & & 2 & -1.3750 & .53131 & -2.588 & 25.954 & .016 \\
\hline
\end{tabular}

Because a Levene Test found that the homogeneity of variance assumption had been violated, $p=.003$, hypothesis tests were based on unequal variances (we should, therefore look at results on the bottom line of table 6.25).

A significant effect was found for the first comparison, which contrasted the control group $(M=7.15, S D=.77)$ with experimental groupA $(M=11.12, S D=1.77)$, $[t(\mathbf{2 0 . 4 3})=\mathbf{- 8 . 2 0}, p<\mathbf{. 0 0 0 1}]$. The second test compared experimental groupA with experimental groupB $(\boldsymbol{M}=\mathbf{1 2 . 5}, \boldsymbol{S D = 1 . 1 7})$, this comparison was also significant $[\boldsymbol{t}(\mathbf{2 5 . 9 5})=\mathbf{- 2 . 5 8}, \boldsymbol{p}=\mathbf{. 0 0 1 6}]$. The research hypotheses $(\mathrm{H} 1$ and $\mathrm{H} 2)$ were therefore confirmed.

To sum up, this study proves that the teaching style implemented affects students' development of the speaking skill. On specific topical knowledge speaking test, Students who were taught using an instructional design that draws on both CBA and MIT outperformed students who were taught using a merely competency based instructional design and students who were taught using the traditional method.

\section{VII- Conclusion}

This study was an attempt to investigate whether students' achievements will be boosted if we incorporate teaching practices that draw on CBE and MIT principles. We had special interest in tracing learners' speaking skill development within a specific academic subject-matter course. To achieve such an aim, a quasi-experimental design was implemented at the level of the English department, Larbi Ben M'hidi university. Three intact groups were chosen randomly to take part in the study (a control group and two experimental groups, $A$ and $B$ ). After the administration of the pre-test, which showed that students had almost the same proficiency level at the beginning of the study, the teacher/researcher employed three different teaching styles over the whole academic year 2015/2016. The control group received no treatment and was taught using the traditional method. Experimental group $A$ was taught using CBA, and experimental group $\mathrm{B}$ was taught using an instructional design that combined CBA and MIT. Participants were then post-tested and the results confirmed the research hypotheses and proved that the incorporation of competency-based+MI-inspired inspired teaching techniques may significantly improve learners speaking skill. 


\section{Appendices}

\section{Appendix A}

\section{The Pre-test}

\section{A) Warm-up Questions:}

1. Hello, Could you tell me your name please?

2. How is it going?

3. Where are you from?

4. Are you a good student?

5. Did you choose to study English? Why?
B) Questions about Language and Linguistics:

1. Do you have any idea what linguistics is? How can you define it?

2. Can you specify what is to be studied about language?

3. What is, according to you, the importance of studying linguistics?

4. How can you define language?

5. What is the importance of language? What do we use language for?

6. What makes human language distinct from other systems of communication?

\section{Appendix B}

\section{The Post-test}

C) Warm-up Questions:

1. Hello, can you remind me of your name please?

2. How are you today?

3. Was studying English your choice?

4. Do you regret $\mathrm{it} / \mathrm{did}$ you change your mind?
D) Questions about Language and Linguistics:

1. What is linguistics?

2. Can you specify what is to be studied about language?

3. How can you define language?

4. Can you explain how linguists' theories differed in identifying what the nature of language is?

5. What is the importance of language? What do we use language for?

6. What makes human language distinct from other systems of communication?

\section{Appendix C}

The Specifications for the Speaking Skill Test

\begin{tabular}{|c|c|c|c|}
\hline Accuracy & & Fluency & \\
\hline Little or no language production & $\overline{1}$ & $\begin{array}{l}\text { Little or no communication. Very } \\
\text { hesitant and brief }\end{array}$ & $\overline{1}$ \\
\hline $\begin{array}{l}\text { Poor vocabulary, mistakes in } \\
\text { basic grammar, very strong } \\
\text { foreign accent }\end{array}$ & 2 & $\begin{array}{l}\text { Utterances sometimes difficult to } \\
\text { understand }\end{array}$ & 2 \\
\hline $\begin{array}{llr}\text { Adequate } & \text { but } & \text { limited } \\
\text { vocabulary, makes } & \text { obvious } \\
\text { grammar mistakes, } & \text { slight } \\
\text { foreign accent } & \end{array}$ & 3 & $\begin{array}{l}\text { Gets ideas across but hesitantly } \\
\text { and briefly }\end{array}$ & 3 \\
\hline $\begin{array}{l}\text { Good range of vocabulary, } \\
\text { occasional grammar slips, slight } \\
\text { foreign accent }\end{array}$ & 4 & $\begin{array}{l}\text { Effective communication in short } \\
\text { turns }\end{array}$ & 4 \\
\hline $\begin{array}{l}\text { Wide vocabulary appropriately } \\
\text { used, virtually no grammar } \\
\text { mistakes, native-like or slight } \\
\text { foreign accent }\end{array}$ & 5 & $\begin{array}{l}\text { Easy and effective communication, } \\
\text { uses long turns }\end{array}$ & 5 \\
\hline
\end{tabular}




\section{Appendix D \\ A Sample Lesson Plan for Experimental Group A}

\section{Lesson Title: Characteristics of Human Language}

\section{Department of English}

Level: $1^{\text {st }}$ Year LMD

Time Frame: 90 mins $x 3$

Resources: Blackboard, chalk, handouts, paper/pencil.

\section{Objectives:}

- Students will be able to demonstrate understanding of, explain, and discuss concepts related to the salient characteristics of human language with the whole class using coherent and cohesive speech.

\section{Target Competencies \\ - Be able to autonomously decipher complex definitions and linguists' statements about features specific to human language.}

- Successful management of the event.

- Engage in a variety of self-development activities.

\section{Procedure:}

\section{Phase 1:}

- Students will be required to prepare reports about seven salient language characteristics and present them in class (the characteristics are: Creativity, displacement, duality, cultural transmission, arbitrariness, discreteness, prevarication).

- Each student will be given the freedom to choose his partner and then students and the teacher will discuss choice of the topics (i.e., the characteristics) each pair will work on.

- Students are made aware of the course objectives and competencies they are required to achieve. 
Phase 2:

- The teacher makes it clear that students should abide by the following instructions when they make class presentations:

$>$ Do not just read and you are invited to improvise.

$>$ Use your voice and body effectively. You have to be intelligent in using the appropriate verbal and non-verbal aspects that will help you get your audience attention and succeed in getting your message across.

$>$ Make your presentation more interactive. You can achieve this purpose resorting to such techniques as asking questions, making polls, and brainstorming in order to build on what the audience have as background information to reach the new information.

$>$ Tend to your classmates' needs and explain further what they cannot fathom.

$>$ Be alert to your classmates' body language and facial expressions and make a good interpretation of such cues. Provide more clarification in case such nonverbal aspects indicate that further explanation is required.

Phase 3:

- Students will make the class presentations following the aforementioned instructions.

- The teacher should not interfere. Only if necessary should he provide students with some indirect feedback to put them on the right track.

\title{
Phase 4:
}

- The teachers provides students with feedback on their performance and re-explains the concepts that have been mis-explained by students.

\section{Appendix E}

\section{A Sample Lesson Plan for Experimental Group B}

\author{
Lesson Title: Characteristics of Human Language \\ Department of English \\ Level: $1^{\text {st }}$ Year LMD \\ Time Frame: 90 mins x 3 \\ Resources: Overhead projector, Computer, speakers, videos, songs, internet, \\ blackboard, chalk, handouts, paper/pencil. \\ Objectives: \\ - Students will be able to demonstrate understanding of, explain, and discuss concepts \\ related to the salient characteristics of human language with the whole class using
} coherent and cohesive speech.

Target Competencies
- Be able to autonomously decipher
complex definitions and linguists'
statements about features specific to
human language.

- Successful management of the event.

\section{Indicators}

- Employ a number of higher-order thinking skills (such as deduction, guessing, making inferences, synthesis, analysis, evaluation and argumentation) in order to attain a good understanding of certain concepts independently (with the guidance of the teacher).

- Demonstrate skill in optimizing content organization.

- Use the appropriate strategies and techniques to successfully transfer knowledge to the audience.

- Make the students' background knowledge usable by relating it to the new tasks.

- Make good use of technological aids.

- Be cognizant of audience engagement (through successful interpretation of body-language for example) while delivering a presentation.

- Change strategies midstream when the 
- Engage in a variety of self-development activities. currently used ones are not working.

-Articulately respond to unrehearsed comments and questions during and after the presentation.

- Plan for the use of self-development strategies.

- Demonstrate willingness to experiment, modify, and evaluate when applying newly acquired knowledge and skills

- Critically reflect on own actions and experiences to identify areas for personal growth.

- Achieve personal growth by accepting and acting upon feedback received from the teacher and peers.

Procedure:

Intelligences Engaged

\section{Phase 1:}

- Students will be required to prepare reports about seven salient language characteristics and present them in class (the characteristics are: Creativity, displacement, duality, cultural transmission, arbitrariness, discreteness, prevarication).

- Each student will be given the freedom to choose his partner and then students and the teacher will discuss choice of the topic (i.e., the characteristics) each pair will work on.

- Students are made aware of the course objectives and competencies they are required to achieve and master.

\section{Phase 2:}

- The teacher makes it clear that students should abide by the following instructions when they make class presentations:

$>$ You should incorporate educational technologies in your presentation: PowerPoint, videos, songs, pictures, ... etc.

$>$ Do not just read and you are invited to improvise.

$>$ Use your voice and body effectively. You have to be intelligent in using the appropriate verbal and non-verbal aspects that will help you get your audience attention and succeed in getting your message across.

$>$ Make your presentation more interactive. You can achieve this purpose resorting to such techniques as asking questions, making polls, and brainstorming in order to build on what the audience have as background information to reach the new information (students are allowed to use dictionaries and the internet).

$>$ Tend to your classmates' needs and explain further what they cannot fathom.

$>$ Be alert to your classmates' body language and facial expressions and make a good interpretation of such cues. Provide more clarification in case such non-verbal aspects indicate that further explanation is required.
VL, LM, IR, IA, N.

VL, LM, IR, IA, BK, SV 
Phase 3:

- Students will make the class presentations following the aforementioned instructions.

VL, LM, IR, IA, BK, SV, $\mathrm{M}, \mathrm{N}$

- The teacher should not interfere. Only if necessary should he provide students with some indirect feedback to put them on the right track.

\section{Phase 4:}

- Students" performance in "phase 3" is tape recorded and in this phase (4) the tapes will be played giving each student the opportunity to self-evaluate his presentation and also comment on his classmates' performance.

- If necessary, the teacher interferes and provides feedback (with the priority given to indirect feedback).

\section{Appendix F}

A Sample Lesson Plan for the Control Group

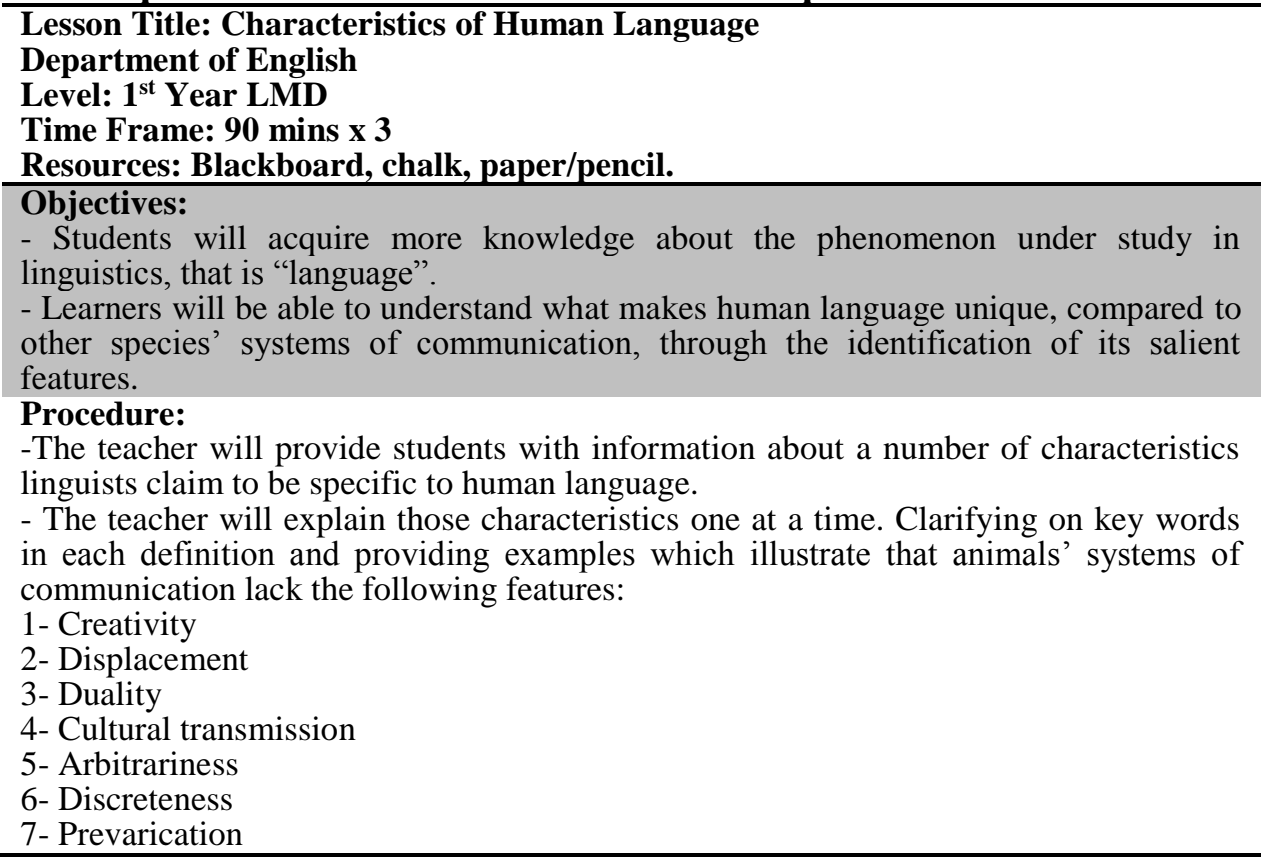

\section{Bibliography}

[1]. Armstrong, T. (2003). The multiple intelligences of reading and writing : making the words come alive. Alexandria, Va: ASCD.

[2]. Burns, R., \& Klingstedt, J. L. (1972). Introduction to competency-based education. In R. Burns \& J. L. Klingstedt (Eds.), Competency-based education: An introduction (pp. 03-06). Englewood Cliffs, N.J: Educational Technology Publications, Inc.

[3]. Chen, J. Q. (2002). Intelligence : Multiple intelligences. In J. W. Guthrie (Ed.), Encyclopedia of education ( $2^{\text {nd }}$ ed) (pp. 1198-1201). USA: McMillan Reference.

[4]. Crawley, M. J. (2015). Statistics : an introduction using R. London: John Wiley \& Sons, Ltd.

[5]. Farhady, H. 2002. Classroom assessment: A plea for change. Retrieved January 12, 2015 from the World Wide Web: www.aua.am/academics/dep/hf.../ClassroomAssessment.pdf

[6]. Gardner, H. 1983. Frames of mind: The theory of multiple intelligences. New York. Basic Books. 
[7]. Gardner, H. 1999. Intelligence reframed: Multiple intelligences for the $21^{\text {st }}$ century. New York. Basic Books.

[8]. Gardner, H. 2003. "Multiple Intelligences after twenty Years". Retrieved July 23, 2015 from the World Wide Web: http://pzweb.harvard.edu/pis/hg_mi_after_20_years.pdf

[9]. Kerr, A. W., Hall H. K., \& Kozub S. A. (2002). Doing statistics with SPSS. Thousand Oaks, California: SAGE Publications, Inc.

[10]. Kincheloe.J.L \& Feltman.T. 2007. Howard Gardner, in J. L. Kincheloe \& R. A. Horn (Eds). The Praeger handbook of education and psychology. (Vol1) [pp81- 87] USA. Greenwood Publishing Group, Inc.

[11]. Larson-Hall, J. (2010). A guide to doing statistics in second language research using SPSS. New York, NY: Routledge/ Taylor \& Francis Group.

[12]. Mason, E.J., \& Wilox, K. 2009. Intelligence: An overview, in E. M. Anderman \& L. H. Anderman.L.H.(Eds) Psychology of classroom learning: An encyclopedia. [pp 497-505] USA. McMillan Reference.

[13]. McKay, R. 2008. Multiple intelligences, in N. Salkind (Ed), Encyclopedia of educational psychology. Vol2. [pp712-717] USA. SAGE Publications, Inc.

[14]. Nunan, D. (2013). Learner-centered English language education: The selected works of David Nunan. New York, NY: Routledge/ Taylor \& Francis Group.

[15]. Seider, S., \& Gardner, H. (2009). Multiple intelligences. In E.M. Anderman \& L.H. Anderman (Eds.), Psychology of classroom learning: An encyclopedia (pp. 635-638). New York, NY: McMillan Reference USA, a part of Gale, Cengage Learning..

[16]. Spady, W. G. (1994). Competency-based education: A bandwagon in search of a definition. In Deakin University Course Development Centre (Eds.), A collection of readings related to competency-based training (pp. 21-31). Victoria, Australia: Deakin University.

[17]. Tavakoli, H. (2012). A dictionary of research methodology and statistics in applied linguistics. Tehran, Iran: Rahnama Press.

[18]. Tele, S. (2000). Rainbows of intelligence: Exploring how students learn. New York, NY: Skyhorse Publishing. 